\title{
Theatre as a means of countering resurgent nationalism and racism in the 21 st century: Seth Baumrin's work in Europe
}

\author{
EWELINA TOPOLSKA
}

Received 31.01.2018, received in revised form 21.07.2018, accepted 30.11.2018.

\begin{abstract}
The paper describes how two European theatre groups, Subpoetics and Gershom, led by an American director, Seth Baumrin, use artistic tools to bring about political and social change. Their creative projects are aimed at combating nationalism and racism, while building a more open and more humane society, based on the dignity and self-respect of the individual, which are considered a necessary precondition of respect for others. The article testifies to the transformative power of the workshops and performances that Baumrin and his associates offer the European public, and the author supports her observations with well-established theories from the area of theatre studies and psychology. As up until now no other academic papers have been published on the subject, a large share of the information included in this article comes from primary sources such as interviews, informal conversations and direct observation.
\end{abstract}

\section{Key words}

performance, workshop, physical theatre, xenophobia, transformation 


\title{
Teatr jako środek oporu wobec odradzającego się w XXI wieku nacjonalizmu i rasizmu: działalność Setha Baumrina w Europie
}

\begin{abstract}
Abstrakt
Artykuł opisuje pracę dwóch kolektywów teatralnych działających w Europie, a prowadzonych przez amerykańskiego reżysera Setha Baumrina, skupiajac się na wykorzystaniu przez nich narzędzi artystycznych w celu promowania politycznych i społecznych zmian. Projekty, o których tu mowa, nakierowane sa na zwalczanie nacjonalizmu i rasizmu oraz działania majace prowadzić do budowy bardziej otwartego i humanitarnego społeczeństwa, którego podstawa jest godność i szacunek jednostki do samej siebie, traktowane jako warunek wykształcenia się szacunku do innych. Artykuł analizuje transformacyjny potencjał warsztatów i performance teatralnych oferowanych przez Baumrina i jego współpracowników europejskiej publice, podpierajac się przy tym ugruntowanymi teoriami $z$ dziedziny studiów teatralnych oraz psychologii. Do tej pory nie powstały żadne artykuły naukowe traktujace o poruszanym tu temacie; $z$ tego te $\dot{z}$ względu większość informacji pochodzi $z$ wywiadów i bezpośredniej obserwacji.
\end{abstract}

\section{Słowa kluczowe}

performance, warsztaty, teatr fizyczny, ksenofobia, przemiana

\section{Introduction}

From its beginnings dating back to ancient Greece, theatre has been a tool of political and social influence, an active voice in the important debates of its day. The relationship of theatre and politics throughout the history of Western civilization has been analysed rigorously by a number of highly-regarded theatre researchers, among them Erika Fischer-Lichte (2008) and Hans Thies-Lehmann (2012). This relationship is holding strong, with such renowned contemporary directors as Peter 
Brooks, Eugenio Barba or Christoph Schlingensief ${ }^{1}$ engaging in heated discussions on nationalism, racism and inter/multiculturalism that are crucial to understanding the present political conflicts of the Western world. Still, theatre artists are not politicians, which is why they use different methods of influence, relying on "indirectness and deceleration, on a reflecting immersion in political topics" (Thies-Lehmann 2010:184). In this article I intend to show how Seth Baumrin, an American director presently working in Europe, uses the tools offered by theatre to combat nationalism, racism and xenophobia, in an effort to contribute to building a more open and more humane society. As Baumrin's European projects and his methodology were developed in the recent years, no major analysis concerning the subject has been published so far. My hope is to fill this gap and provide information on the socially valuable and artistically compelling initiatives headed by Seth Baumrin to a larger circle of readers interested in theatre studies and theatre applications.

\section{From America to Europe: Seth Baumrin's trajectory and mission}

Before 2014 Seth Baumrin carried out his professional activity mainly in the United States. Born in Baltimore, Maryland, in the 80s Baumrin participated in a series of trainings organized in New York by the famous Polish theatre director, Jerzy Grotowski. These, as well as the opportunity to practice under the supervision of Grotowski's associate, Jacques Chwat, proved to be a turning point for Baumrin, ${ }^{2}$ who decided to dedicate his life to the stage. By 2018 he had directed over 60 performances/plays, and this impressive practical experience has been accompanied by theoretical reflection - Baumrin au-

1 Sadly, deceased in 2010.

2 Most information on Baumrin's professional trajectory and his work based on a series of interviews carried out by the author in the period from Jan to June 2017. 
thored numerous articles and two books on the subject. ${ }^{3}$ In 2011, in recognition of his artistic and intellectual effort, Baumrin was awarded the position of the Chair of the Communication and Theatre Arts Department at the John Jay College of Criminal Justice in New York, which he holds to this day (July 2018).

A descendant of Ukrainian Jews who fled persecution during World War II and an ardent follower of Eastern European theatre masters, ${ }^{4}$ Baumrin has always felt attracted to the old continent, collaborating with many European artists and visiting Poland and Ukraine for research. Ultimately, in 2014, his connection with Europe evolved into a firm bond, when his first European-based, but in fact intercontinental artists' collective, Subpoetics, was born.

Subpoetics originated in France, where the director met the other founding members of the group: Madeleine Bongard (Switzerland) and Eva Goldenberg (France). Later, more performers of Jamaican, Haitian, French, Austrian and Iranian origin, joined, and the first performance Port d'Alger 1962 was presented to the public. It was built on a series of photographs from the Algerian Revolution which provided a point of departure towards constructing some physical actions. The theatre Seth Baumrin directs is largely based on improvisation, and as the actors evolved and the members of the group changed, the group felt a need to rename the performance.

The show's later title, Nomansland, perfectly reflects the idea underlying the whole project: to quote Vernice Miller, one of the co-creators of the performance, it is "to make theatre a weapon to fight ethnic stereotypes resulting from xenophobia". Baumrin, as a professor at the John Jay College of Criminal Justice in New York, a direct witness of the World Trade Centre attack in 2001, and last but not least, a member of

3 Full description of Baumrin's professional trajectory available at: <http://www.jjay.cuny.edu/sites/default/files/faculty/cv/Seth\%20Baumrin $\% 20 C V \% 2011417 \_0 . p d f>$.

4 Apart from Grotowski, Baumrin mentions among his important inspirations such names as Stanislavsky, Meyerhold or Vakhtangov. 
a long-persecuted diaspora, demonstrates both in his private and professional life a particular concern for social justice, and views art as a powerful tool in creating social change.

How may this change be brought about? By the physical copresence 5 and exchange of life energy. Baumrin, trained by Jerzy Grotowski and Eugenio Barba, great masters of physical theatre, tries to build an intimate connection between the performers and the spectators, creating such waves and bursts of emotion and energy that the audience cannot help but be engulfed and swept away by them. Turning to quantum physics, the director analyses the process of energy exchange between the performers and the spectators in a paper entitled: "Centripetal and Centrifugal Forces: On the Value of Actor and Theatre Group Autonomy in the 21st Century (Jerzy Grotowski at the Fifth Circle Railway Station)". At the beginning of the text he insists:

For a theatre group to function effectively (autonomously or as part of a larger cultural program, i.e. a national, commercial, or academic theatre), two forces must co-exist and both cohere in the group: A centripetal force that nurtures actors individually, collectively, holistically, as wholly human, which protects the group, keeping it together. Concurrently, a centrifugal force that permits the actor and the group to transmit their work product to the public. That transmission should have such an impact that the performance's waves of energy, which also may be named the idea of theatre, reach beyond the immediate public to modulate within the greater cultural body - society. (upcoming Baumrin 2017: 1)

As the Subpoetics actors come from different cultural backgrounds and speak different languages, the audience, always situated close to the centre of action (Baumrin avoids traditional space distribution, with a clear division between the stage and the stalls), is submerged in a dense multisensory

5 This aspect of a performance is analysed in detail by Fischer-Lichte in The Transformative Power of Performance, chapter "Shared bodies, shared spaces: the bodily co-presence of actors and spectators" (2008:38-74). 
and multicultural experience, during which gushes of foreign, unintelligible words, melodies and very intense emotions cross their bodies. Realizing the ideal of a theatre gathering as a temporal community of strangers, Baumrin creates in his postdramatic ${ }^{6}$ performances intimate connections between the bodies and the senses of those present. It is difficult to imagine that after experiencing the humanity of the other so directly, after sharing in the performers' profound physical authenticity whose primordial power is attenuated by the spellbinding rhythmicity of movements and sounds, one could continue to reject another human being because of that otherness, be it their colour, race or nationality. ${ }^{7}$

\section{A stranger (but not quite) in Ukraine: Project Gershom}

The same technique is employed in the work of another European group led by Baumrin, the Ukrainian collective Gershom (again, it is important to mention that the boundaries between the two groups tend to be fluid). Its members are mainly former students (2017 graduates) of the Faculty of Culture and Arts of the Ivan Franko National University of L'viv. Baumrin met them for the first time in 2015 during one of his research trips to Ukraine, when he was asked to lead an actor training for this group. The cooperation turned out to be so satisfactory to both parties that it became permanent, ultimately resulting in an ambitious and successful project of opening a new theatre space in the artistic city of L'viv, where Gershom found its abode.

The name resonates with Baumrin's deepest concerns - according to the Bible Gershom means "a foreigner in a foreign land" (Ex 18:3). On the other hand, Daniel Hillel explains that

\footnotetext{
6 As defined by Hans Thies-Lehmann (2010).

7 However, it must be admitted that such an experience may not be welcomed enthusiastically by everyone - in December 2016 in Opole I witnessed a situation in which a member of the audience behaved in a clearly defiant or even abusive way towards the performers. Still, hostile or otherwise disturbing reactions to Subpoetics' performances are rare, the contrary being the norm.
} 
[t]he name Gershom has multiple connotations: ger means stranger, garish means "drive away", and sham means "over there". So, in a single name, Moses manifested his initial condition as one driven away from his native country and made to live as a stranger in a faraway land. (Hillel 2006:108)

And another Bible commentator, James K. Bruckner suggests that the wordplay "could also imply the irony that he [Moses] is at home as a stranger in Midian" (2012: $\S 3$ ). This connects further with an admonition uttered by God in Ex 22:2 "Do not mistreat a foreigner or oppress him, for you were foreigners 8 in Egypt". Similarly, when asked to elucidate his choice of the company name, as well as the meaning of the title of the group's first public performance, Stranger in a Strange Land (2016), Baumrin stated:

We are all strangers even in our country. So I look to the young people - my students in New York, my students here - they are going to inherit the world with environmental problems, with a crazy economy. So that word - even if it comes from a Bible story, I think it really speaks to experiencing the 21 st century. I'm a father and I want to be perfect to my children, but I would not want to be dishonest to my children about the world that they are going into. When we push somebody to the outside because we don`t understand them it's very painful. (Gienda 2017)

This is why Baumrin points to the fight against xenophobia as an umbrella goal of his recent artistic projects. However, for this fight to be effective, it has to take place on a visceral, intuitive level, as confirmed by recent discoveries in moral psychology (Haidt 2013). To the chagrin of many, human beings once again turn out to be fundamentally emotional (as opposed to rational) creatures who may react better to indirect ways of persuasion than to rational arguments. In this context, art may definitely be treated as a powerful tool of persua-

8 Modern English translations of the Bible use here alternately the nouns "aliens", "strangers" or "foreigners". 
sion, especially when employed by such dedicated and talented actors as the members of Subpoetics and Gerhsom.

The author of the present article had an opportunity to witness the immediate impact of Baumrin's theatre and the reactions it elicited in the audience when attending a conjoint performance of the two groups in Opole in December 2016. Most of the spectators, used to a more traditional and, in a way, conservative repertoire, were visibly moved and some congratulated Baumrin warmly for the unusual, but (in their opinion) very enriching experience.

\section{The texts: A choir conducted by Walt Whitman}

Although it is to be assumed that most of the spectators in Poland and other countries where Gershom and Subpoetics have toured (Ukraine, Slovenia, France) are not able to decipher the words spoken on stage, their choice is far from accidental, even if the actors are allowed a far-reaching autonomy in that field. Neither in Nomansland nor in A Stranger in a Strange Land is it possible to find a linear argument based on a pre-prepared, pre-recorded story. Still, as confirmed by the author of the present article's observations of the rehearsals, ${ }^{9}$ the actors' work is based on a coherent narrative whose existence may not be easily detectable for the spectators. What reaches their ears is a mixture of mostly unintelligible texts and songs, which nevertheless captivate their attention through enchanting rhythms and heart-stirring harmonies. Analysing the textual level of the above-mentioned performances in detail would require a separate article; at this point I mention only a few representative examples of the texts and authors Baumrin and his associates felt inspired by.

A prominent figure recurring throughout a large share of Baumrin's work is Walt Whitman. A great admirer of humanity, nature and life at large, this American poet is a perfect ex-

9 I had an opportunity to participate in Subpoetics' and Gershom's rehearsals in December 2016 in Poland and in January 2017 in Ukraine. 
ample of what Erich Fromm calls the biophilic attitude, an attitude promoting the growth and happiness of all living beings. ${ }^{10}$ Baumrin, who himself seems deeply concerned with the well-being of people in his community and beyond, finds Whitman's poetry irresistible enough to employ it in all of his European shows (at least at some stage of creation - as the performance evolves, the selection of texts tends to change). Thus, for example, in Stranger in a Strange Land we could hear Vira Tsikhatska, a Ukrainian actress, recite a fragment of the "Song at Sunset":

I sing the Equalities, modern or old,

I sing the endless finales of things;

I say Nature continues - Glory continues;

I praise with electric voice;

For I do not see one imperfection in the universe;

And I do not see one cause or result lamentable at last in the universe. (Whitman 2009:179)

Nevertheless, Whitman is only one of a long list of poets, musicians and political activists evoked in the performances. In Stranger..., Baumrin introduced texts by such renowned advocates of human dignity as Mahatma Ghandi or Malcolm X. He also took care to include pieces by prominent representatives of ethnic minorities in the United States, such as Gwendolyn Brooks and Sonia Sanchez. Spectators who are able to understand the original texts without translation and are well-versed in American culture will instantly recognize Baumrin's ambition to establish a dialogue with, and continue the tradition of, the civil rights movement.

10 Defined in Erich Fromm's The Heart of Man: Its Genius for Good and Evil (2010). 


\section{How to make a truly democratic theatre: Subpoetics methodology}

Still, it would be incorrect to assume that the performances are dominated by explicit references to the politics of inclusiveness or the fight for human rights. Just as Hans ThiesLehmann, Baumrin seems to believe that

[t]heatre is not political because of its content, although it is possible, but it should be made in a political way. That is essential. It should be made in a democratic spirit of cooperation and mutual acceptance, leaving aside a hierarchical style and power relations. (in Soto $2017^{11}$ )

Hence Baumrin's decision to let the performers shape the show to a large extent, which includes their freedom to pick and change texts in accordance with their preferences and needs. As a consequence, apart from texts and authors promoting human rights and democracy, both in Subpoetics' and Gershom's performances we can hear a myriad of seemingly disconnected voices - fragments of Jack Kerouac's "The Brooklyn Bridge Blues" are intertwined with the biblical "Song of Songs", a Russian war song "Temnaya Noch" ("The Dark Night") is followed by Peter Handke's famous poem "Als das Kind Kind war" ("When the child was a child"), and a superb interpretation of Yuriy Izdryk's "A Prayer" ("Молитва") contrasts with Bob Marley's hit "Redemption Song". However, the final impression is that all of these voices converge into a consistent, although not easily decipherable, story. Talking about the Subpoetics Methodology, which later gave its name to the first European theatre collective led by Baumrin, the director explains how this confluence is achieved:

[...] in Subpoetics the actor is like three trains traveling on a single track, all in the same direction and at the same time. When this is achieved, the story and theme emerge, adding the fourth

11 Translation by E. Topolska. 
train to the track. The actor is the railroad track. The first train is the actor's body and voice - his/her physical self. The second train consists of the chosen texts that are spoken and sung by the actor. The third train is the actor's inner reality in which s/he clarifies and justifies how the first two trains can both be on the same track. Since the performer's actions emerge from arduous physical and vocal training that lasts for hours every day, the actors are at first disconnected from their texts. In the third step, the actor matches the actions and voices to the texts by telling him/herself stories - secret stories unknown to others. The way in which the secret stories connect the texts to the actor's physical actions are the subpoetics. (Baumrin in Glej Theatre pamphlet, November 2016)

The director insists that the performers should find their truth, connecting their body and the text via a story that is real and meaningful to them, as only in this way, by combining different individual and at the same time convincing stories, a spectacular global effect can be achieved. When interweaving their particular stories to create a whole, the performers and the director construct a more traditional dramatic structure with a beginning, a middle, and an end. That does not mean, however, establishing predictable cause-effect relationships and relying on a linear narrative. Rather, it means finding artistic and emotional logic that allows the spectators to enter a state of non-rational flow, ${ }^{12}$ in which all languages and races come together in harmony.

\section{Opole: Theatre and pedagogy}

There seems to exist a general consensus among the artists collaborating with Baumrin that a part of their activity should involve the education of younger generations. This goal is realized through workshops accompanying the performances, as

12 In her famous book The Transformative Power of Performance. A New Aesthetics (2008) Fischer-Lichte uses the term "enchantment" to describe this state of "deeper experience of being in the world and becoming newly conscious of that being" (Carlosn in Fischer-Lichte 2008). 
well as through the project Gershom, created for and by students.

One such workshop took place at the end of November 2016 at the University of Opole, Poland. It was led by a Subpoetics member, Sylvain Paolini, with a little help from the author of this article, which provided an opportunity to observe this kind of work as a direct witness. Approximately 15 students participated in the workshop (the number varied on different days), training for 12 days in a row. During that time Paolini and I were able to notice gradual changes in the students, both on the individual level, as well as in the group dynamics. The goal of most physical theatre exercises (or actor training in general) is to find and deepen the consciousness of one's body, which in turn allows one to move and express one's self in a more authentic, but at the same time controlled and self-confident way. Just as actors have to be able to speak in front of an audience, those participating in actor training naturally acquire more courage to expose themselves and take a stance in public, as they speak from the sense of integrity, feeling more in control, stronger, being able to stand their ground and fend off possible attacks. During the Opole workshop Paolini and I had a great opportunity to observe these young people, some of them very shy and inhibited, break their barriers, overcome their complexes and every day become bolder, braver and visibly more satisfied with themselves, as they were letting their personalities and their innate creative potential unfold. It must be admitted that not everyone was ready and willing to undergo such changes - some of the participants abandoned the workshop precisely because of being encouraged to face their inhibitions; still, the general tendency was that of enthusiasm and growth.

It was uplifting to see how, within a couple of days, strong bonds developed between these perfect strangers, as only a few participants had been acquainted prior to coming to the workshop. They established very specific bonds, built on elements 
typical of rituals ${ }^{13}$ - physical proximity, touch, very close cooperation, repetition of movements and facial expressions of all the members, and finally trust, as many exercises required closing one's eyes and letting another person guide. Nowadays, when the problem of general emotional starvation caused, among other factors, by the disintegration of small communities $^{14}$ is becoming a major concern, the value of such emotional bonds, which are inherent in theatre groups and workshops, is not to be underestimated. ${ }^{15}$

\section{Theatre as an incubator of respect for the life of another human being}

The question remains, however, how is all of this supposed to protect us from hatred and violence ensuing from nationalist and racist ideologies?

In order to provide an answer, let us dwell for a while on another question: what is the profile of the people who embrace such ideologies?

Erich Fromm, one of the leading 20th century researchers of the relationships between people's psychological mechanisms and authoritarianism, dedicated a large share of his work to identifying the psychological background that makes people susceptible to developing hatred towards other ethnic groups. In his 1964 book, "The Heart of Man", Fromm propos-

13 Ritual understood in the same way as the founder of theatre studies in Germany, Max Hermann, defined it - "the prevalence of bodily acts and the coming into being of a community as a result" (Fischer-Lichte 2005: 28).

14 On the importance of small communities and face-to face contact that is fading away in our digitalized world, taking a serious toll on our mental and physical health see "The Village Effect: Why Face-to-Face Contact Matters" by Susan Pinker (2015).

15 It must be admitted, just as Eugenio Barba does in his letter to Richard Schechner, that tight communities are at risk of evolving into tribes that exclude or even become hostile towards others; still, "When fundamentalist movements cannot sustain themselves by force, when they are restricted to the use of cultural weapons, they become substantially innocuous" (Barba 1995: 143). 
es to conceptualize nationalism as group narcissism. He explains:

For those who are economically and culturally poor, narcissistic pride in belonging to the group is the only - and often a very effective - source of satisfaction. Precisely because life is not "interesting" to them [the people], and does not offer them possibilities for developing interests, they develop an extreme form of narcissism. Good examples of this phenomenon in recent years are the racial narcissism which existed in Hitler's Germany, and which is found in the American South today. In both instances the core of the racial superiority feeling was, and still is, the lower middle class; this backward class, which in Germany as well as in the American South, has been economically and culturally deprived, without a realistic hope of changing its situation., has only one satisfaction: the inflated image of itself as the most admirable group in the world, and of being superior to another racial group that is singled out as inferior. The member of such a backward group feels: "Even though I am poor and uncultured I am somebody important because I belong to the most admirable group in the world - I am white" or "I am an Aryan". (Fromm 2010: 76-77)

In the same book Fromm affirms that impotent people, deprived of the possibilities to transcend themselves in a positive way, will necessarily develop negative compensatory mechanisms, of which violence is the most common.

How can active involvement with theatre, such as attending a workshop, help oppose such tendencies? Actor training provides participants with tools that help them become more selfconfident, enterprising and creative. It helps them discover their latent potential and gives them an impulse to pursue their individual dreams instead of drowning in despair or hiding behind a comfortable but illusory shield of group narcissism - nationalism.

During the workshops offered by Subpoetics and Gershom, one has a chance to discover inside oneself a stronger, talented and more dignified human being, a human being that does not need to dissolve his or her identity in a powerful gang in 
order not to feel disdained by the rest of the society for his or her lack of resources (of all kinds), but who is accepted and cherished within a group of equals as a valuable member capable not only of receiving, but also of giving. ${ }^{16}$ Most forms of theatre training let the participant enlarge their mental and emotional horizons through unearthing or creating new layers and capacities that shape our identity. ${ }^{17}$ The richer personalities we have, the more mature and emotionally intelligent we are, the more inclined we feel to perceive ourselves as deserving of respect and love. And as Fromm affirms, love and respect for oneself and one's life is a necessary precondition of respect for the lives of others (Fromm 2010).

Still, the transformative power of theatre does not necessarily require active participation; performances, especially performances as intense as those offered by Gershom and Subpoetics, in essence are events that impose the need for some form of participation, in this case sensual and emotional. Baumrin and his associates prepare for the audience "a liminal experience which can lead to transformations or which is in itself already experienced as transformative" (Fischer-Lichte 2008:190). The desired transformation is rejecting xenophobia; however, it is not encouraged by admonishing the public from the position of authority, but through "an aesthetic of responsibility (response-ability) [...] [requiring] a mutual implication of actors and spectators in the theatrical production of images" (Thies-Lehmann 2010:185-6). In such a situation, uncon-

16 Which is crucial for well-being, as Fromm assures us: "Giving is the highest expression of potency. In the very act of giving, I experience my strength, my wealth, my power. This experience of heightened vitality and potency fills me with joy. I experience myself as overflowing, spending, alive, hence as joyous. Giving is more joyous than receiving, not because it is a deprivation, but because in the act of giving lies the expression of my aliveness" (Fromm 1995: 20).

17 This transformative influence on the psyche allows the theatre to be a very efficient means of therapy. Cf. Jennings (1998) or Jean-Pierre Klein, the founder of Institut National d'Expression, de Création, d'Art et Thérapie in Paris, who affirms in his book Theatre and Dramatherapy: "Dramatherapy in inchoative - it incites movement, difference, alterity of the I; it unchains a process, sets fire to the fuse of an explosive [...]" (Klein 2017: 129; trans. from Spanish E. Topolska). 
scious processes are triggered. And these processes are the arts' main area of operation.

\section{Conclusions}

Obviously, theatre is not the only way of preventing people from falling into the snares of nationalism, racism or other types of inter-group hatred that closed societies ${ }^{18}$ are based on. However, the author of this article does claim that, if used adequately, it may be a very efficient means of protection. The authoritarian regimes know this only too well, going to great lengths to destroy this method of developing stronger, more independent and more active citizens that would question the group-think and search for constructive, instead of destructive, forms of expression of their human potential. ${ }^{19}$ At this moment, when an augmenting wave of nationalism and racism is rolling through the Western democracies, and when urgent global problems require of us that we leave behind the outdated $^{20}$ 18th century notions of state and race, initiatives like Subpoetics and Gershom, opposing xenophobia and enhancing empathy, courage, community-building, the individual's creative potential, and, last but not least, celebrating the in-

18 I am drawing here on the distinction introduced by Karl Popper between a closed and open society, with the latter "aiming at humaneness and reasonableness at equality and freedom" (Popper 2011: XXXV).

19 Personal experience of one of the Subpoetics members, Alireza Daryanavard, is a good illustration of this thesis. Born in 1995 in Iran, Daryanavard was persecuted, imprisoned and mutilated by the Iranian regime (prison guards broke both of his legs) as a consequence of his engagement with dance and actor training/experimentation. Finally, in 2014 he was granted asylum by the Austrian government (source: interview by the author).

20 And clearly artificial, as explained already in 1937 by José Ortega $\mathrm{y}$ Gasset The Revolt of the Masses: "More than anything else, a State is a project of doing something and a program of cooperation. People are called to do something together. It is not about blood relationships, linguistic unity, territorial unity or contiguity of residence. It is nothing material, inert, given and limited. It is pure dynamics [...] (2002: 209; trans. from Spanish by E. Topolska). 
herent worth of human life and promoting responsibility for this life, are very much needed. The theatre of Seth Baumrin and his associates is a great celebration of human growth and human life, to which nationalism and racism are contrary forces, as history has made obvious on too many occasions.

\section{References}

Barba, Eugenio (1995). The Paper Canoe: A Guide to Theatre Anthropology. Trans. Richard Fowler. London - New York: Routledge.

Baumrin, Seth (2017). "Centripetal and centrifugal forces: On the value of actor and theatre group autonomy in the 21 st century (Jerzy Grotowski at the fifth Circle Railway Station)". Private collection.

Bongard, Madeleine. Available at $<$ https://madeleine.book.fr/port-dalger-1962>. Accessed 18.07.2018.

Bruckner, James K. (2012). Exodus (Understanding the Bible Commentary Series). United States: Baker Books.

Carlson, Marvin (2008). Introduction. In: Erika Fischer-Lichte (ed.). The Transformative Power of Performance: A New Aesthetics. Trans. Saskya Iris Jain. London - New York: Routledge.

Curriculum Seth Baumrin, John Jay College of Criminal Justice official site. Available at <http://www.jjay.cuny.edu/sites/default/fil es/faculty/cv/Seth\%20Baumrin\%20CV\%2011417_0.pdf >. Accessed 18.07.2017.

Fischer-Lichte, Erika (2005). Theatre, Sacrifice, Ritual: Exploring Forms of Political Theatre. Trans. Freddie Rokem. London - New York: Routledge.

Fischer-Lichte, Erika (2008). The Transformative Power of Performance: A New Aesthetics. Trans. Saskya Iris Jain. London - New York: Routledge.

Fromm, Erich (1995). The Art of Loving. London: Harper Collins. Fromm, Erich (2010). The Heart of Man: Its Genius for Good and Evil.

New York: American Mental Health Foundation.

Gienda, Olia (2017). "World is in a mess". Syg.ma, 16.05.2017. Available at <http://syg.ma/@olia-gienda/world-is-in-a-mess-1>. Accessed 20. 07. 2017.

“Glej, List!" Glej Theatre pamphlet, November 2016. 
Haidt, Jonathan (2013). The Righteous Mind. London: Penguin Books.

Hillel, Daniel (2006). The Natural History of the Bible. New York: Columbia University Press.

Jennings, Sue (1998). Introduction to Dramatherapy: Theatre and Healing. London - New York: Jessica Kingsley Publishers.

Klein, Jean-Pierre (2017). Teatro y dramaterapia. Trans. Elisenda Julibert. Barcelona: Octaedro.

Ortega y Gasset, José (2002). La rebelión de las masas. Madrid: El País.

Pinker, Susan (2015). The Village Effect: Why Face-to-Face Contact Matters. London: Atlantic Books.

Popper, Karl (2011). The Open Society and Its Enemies. London - New York: Routledge.

Soto, Ivanna (2017). "Hans-Thies Lehmann: 'E1 teatro no es politico por su contenido, sino porque está hecho de un modo político". Clarin, Revista Ñ 15.08.2012. Available at <https://www.clarin. com/teatro/hans-thies-lehmann-teatro-posdramatico-politico_0_ B15w7Tx2wmx.html>. Accessed 20.07.2017.

Thies-Lehmann, Hans (2010). Postdramatic Theatre. Trans. Karen Jürs-Munby. London - New York: Routledge.

Thies-Lehmann, Hans (2012). Das Politische Schreiben. Berlin: Theater der Zeit.

Whitman, Walt (2009). Leaves of Grass. Ed. Jason Stacey. Iowa City: University of Iowa Press.

\author{
Ewelina Topolska \\ ORCID iD: 0000-0003-1077-992X \\ Uniwersytet Gdański \\ Instytut Filologii Romańskiej \\ Wita Stwosza 51 \\ 80-308 Gdańsk \\ Poland \\ evetop@hotmail.com
}

